\title{
Real Estate Asset Management Companies' Economies of Scale: Is It a Dream or Reality? The Italian Case
}

\author{
Evita Allodi $\left(\mathbb{D},{ }^{1}\right.$ Claudio Cacciamani, ${ }^{1}$ Michele Caliolo, ${ }^{2}$ Pier Paolo De Santis, ${ }^{2}$ \\ Fabio Della Marra, ${ }^{1}$ and Simona Sanfelici ${ }^{1}$ \\ ${ }^{1}$ Department of Economic and Business Sciences, University of Parma, Parma, 43125, Italy \\ ${ }^{2}$ Mazars, Milan, 20154, Italy \\ Correspondence should be addressed to Evita Allodi; evita.allodi@unipr.it
}

Received 2 January 2020; Revised 5 April 2020; Accepted 27 April 2020; Published 27 May 2020

Guest Editor: Marco Locurcio

Copyright (C) 2020 Evita Allodi et al. This is an open access article distributed under the Creative Commons Attribution License, which permits unrestricted use, distribution, and reproduction in any medium, provided the original work is properly cited.

The research focuses on a sample of 26 Italian real estate asset management companies (Società di Gestione del Risparmio "SGR") - whose asset management is totally linked to real estate funds-that considers a period of six years (2013-2018). Using some variables extrapolated from the internal accountability of each SGR, the analysis investigates possible relationships between them to verify the presence or absence of economies of scale of Italian real estate management companies by multivariate regressions. The results show that there is no single model for profit maximization and cost minimization, but all depends on the business model that each SGR decides to adopt.

\section{Introduction}

Both researchers and professionals agree that numerous and significant changes affected the real estate industry over the last twenty years [1-7]. The uncertainty about the trend in the real estate industry in the near future is high and is expected to increase [8]. Anyway, with quantitative easing and negative interest rates in Europe, attention in real estate asset class is more and more increasing.

Finance is gaining progressively more importance in every macroeconomic industry, in general, and in the real estate market, in particular [1,9-11].

The main role of finance is to raise funds at the lowest cost. Real estate is a "capital intensive" industry and needs a lot of capital, from the smallest development operations to the largest investments. Finance is also useful in investment analysis; real estate represents an important asset class in both institutional and private portfolios. Analyzing the real estate investment with a financial approach is therefore fundamental. In fact, more and more space has been given to the evaluation of all economic, income, equity, and financial factors affecting the management of real estate portfolios with a consequent impact on the portfolio ability to produce profit. These quantitative factors became as significant as the qualitative (material and architectural) characteristics of real estate [12].

On the other side, the number of companies offering services in the real estate market increased, resulting in higher competition both nationally and internationally [1]. All this led to greater exposure of national operators to threats and opportunities with consequent competitive challenges [13-15]. In this scenario, the real estate industry faced several changes, increasingly dealing with new logics and stakeholders, with ever-changing organizational and structural dynamics. This continuous transformation implied more and more interest in the organizational models of the companies providing asset management services (in Italy, the so-called "Società di Gestione del Risparmio"-SGR).

This interest is also due, on the one hand, to the need to identify more efficient production assets (in a context of reinvigorated requests for the protection of investors in financial instruments exposed to stock market turbulence) and, on the other hand, to the increase of demand for improving the quality of the offered services [16]. 
These structural and organizational changes led over the years to mergers, acquisitions, and consolidation of real estate asset management companies, with a consequent increase in company size. Economies of scale are the cost advantages that companies gain from their scale of operation (typically measured by the amount of output produced), with cost per unit of output decreasing with increasing scale.

By transferring this notion to the real estate asset management industry, it can be assumed that as real estate portfolios increase in size, the incremental cost of managing additional properties should fall $[17,18]$. So real estate asset management companies with larger property portfolios should be more efficient than those with smaller portfolios [19].

While most previous studies focused on the economies of scale in US Real Estate Investment Trusts (REITs), this analysis aims to show, starting from the financial statement data, that there are no specific economies of scale in Italian real estate management companies.

This study briefly summarizes the literature on the subject and the issues arising on the matter. Then, considering some empirical research variables, it tries to find some relationships between them to verify the presence or absence of economies of scale of Italian real estate management companies using multivariate regressions. The results show that there is no single model for profit maximization and cost minimization, but all depends on the business model that each SGR decides to adopt.

\section{Related Literature}

The concept "economies of scale" means that efficiency in production and operations increases with size. Historically, firms in various industries often expand not only to consolidate their power, but also to capture these efficiency gains [17].

In the real estate market, this type of study started to be developed mainly from American REITs.

The first studies, dating back to the 70 s and 80 s, tried to find economies of scale. Anyway, it resulted difficult to identify and measure economies of scale due to the different technologies available and the lack of data [17]. In fact, early studies suggested a "small firm effect" in American REITs: smaller companies earned higher average returns than larger companies [20].

At the beginning of the 90s, researchers found some lower costs coming from the increase in the size of REITs.

Linneman [21] notes that large REITs can achieve greater shareholder value via economies of scale with respect to costs.

Bers and Springer [22] show that economies of scale exist for REITs and also that economies of scale differ chronologically. The same researchers [22-24] and others [25], using the standard approach of estimating the cost function without allowing for the possibility of inefficient production, find evidence of economies of scale for REITs. Capozza and Seguin [26] find that only general and administrative costs exhibit substantial economies of scale. Latzko [27] find economies of scale in managing mutual funds.
Ambrose et al. [25] report that large REITs have higher net operating income (NOI) growth, but they also show that this ratio is weak. In the same year, Capozza and Seguin [28], contradicting what was reported only two years earlier, find evidence of diseconomies of scale. In their study, Anderson et al. [29] measure technical efficiency and economies of scale for REITs by employing data envelopment analysis (DEA), a linear programming technique. They find that REITs are technically inefficient. In particular, inefficiencies are a result of both poor input use and failure to operate at constant returns to scale. The dynamics emerged for the American REITs have recently been tested in the European real estate market by Ambrose et al. [19], investigating the effect of firm size on expense, revenue, return, and capital cost for European real estate companies and comparing the size effects of REITs and non-REIT real estate companies. They found that larger real estate companies are able to generate higher revenue per unit of company size, incur lower costs, and produce higher returns. Moreover, NOI ratios and return ratios increase while selling, general and administrative cost ratios decrease with the size of a company.

The question of the existence of economies of scale in real estate companies still remains important [19]. Even if there is not yet an answer for this question, disagreements about the concept of scale economies in real estate asset management continue to exist.

The uncertainty on the possible existence of economies of scale in the real estate industry is due to multiple factors. First factor being the market, which is characterized by cycles of expansion and of contraction influencing its trend. Secondly, it is difficult to quantify economies of scale: it is easy to identify the presence or absence of economies of scale in industries where production is quantified and measured. In most manufacturing industries, the final output is always an equal product generated by clear and defined input processes. In the analysis of real estate management companies, not only the final output is not easy to identify, but it is not even homogeneous. Third, the assumption underlying in the studies on economies of scale is that all the companies of the sample under investigation can benefit of the same frontier of costs and use the same technology [17, 30]: reality is quite different. Fourth, young, growing, and expanding businesses need time to achieve the right size to ensure economies of scale. No research directly addresses the existence of scale economies in Italian real estate asset management companies: SGR.

There are very few studies focused on Italian asset management companies in general $[16,31,32]$ in which an analysis is carried out considering balance sheet multiples [31] or company X-efficiencies measured to estimate a possible efficient frontier $[16,32]$. Almost absent are the research studies referring to the Italian real estate management companies: only Abate [33] and Giannotti and Mattarocci [34]. Both these papers show that the Italian real estate companies represent a sector that, after a few years of constant and high growth, did not reach the typical maturity of the asset management industry.

The possible reason is, on the one hand, the difficulty in identifying a univocal and truthful representation of the 
production process of the asset management industry in the real estate industry and, on the other, the total lack of data. In fact, SGRs (companies that mainly manage real estate investment funds-closed funds) are not obliged to be listed on the stock exchange.

This analysis aims to demonstrate, starting from the financial statement data of SGR, that there are no economies of scale for the Italian real estate management companies.

\section{The Sample}

The research focuses on a sample of 26 asset management companies (25 (the number of SGRs decreases by one unit because two SGRs have merged) in the years 2017 and 2018) whose asset management is totally based on real estate funds. With reference to the number of SGRs active in Italy, the sample constitutes the $96.30 \%$ (it was not possible to analyse $100 \%$ of the SGRs operating in Italy because one of them is in extraordinary administration) of the population; consequently, the database is almost representative of reality. The assets managed by the companies included in the sample, as of 31 December 2018 , amounted to 70 billion euros, corresponding to $85 \%$ of the total AUM managed by all real estate asset management companies operating in Italy, calculated by the Bank of Italy at 82 billion euros [35].

The variables taken into account were extrapolated from the SGRs' confidential internal accountability which they provided to the research team.

The sample, considering a period of six years (2013-2018), is divided into three different clusters, identified on the basis of the assets under management (AUM) managed by each company included in the sample. The three clusters were identified by setting thresholds based on the AUMs of each SGR as follows:

(i) Cluster 1: average AUM $>5$ billion euros

(ii) Cluster $2: 2$ billion euros $\leq$ average $\mathrm{AUM} \geq 5$ billion euros

(iii) Cluster 3: average AUM $<2$ billion euros

Obviously, from one year to the next, SGRs may change clusters. The variables describing each of the 26 SGRs are the following five:

(1) Net fees: they represent the amount of the budget line no. 30 of the SGRs' income statement scheme, according to the Instruction of Bank of Italy named "Il bilancio degli intermediari IFRS diversi dagli intermediari bancari"

(2) Asset under management: this variable is equal to the sum of the total assets of the all real estate alternative investment funds managed by every SGR of the sample, at the end of the year

(3) Administrative costs: they are the amount of the line no. 120 of the SGRs' income statement scheme, according to the Instruction of Bank of Italy named "Il bilancio degli intermediari IFRS diversi dagli intermediari bancari"
(4) No. of real estate funds managed: this variable is equal to the number of the real estate alternative investment funds managed at the end of the year, as reported in the explanatory note of the SGRs' annual financial statements

(5) Average number of employees: this variable is equal to the average number of employees of the year, as reported in the explanatory note of the SGRs' annual financial statements

In order to make the variables comparable, they have been standardised, i.e., the following transformation has been applied for each variable $x$ :

$$
x=\frac{x-E(x)}{\sigma_{x}},
$$

where $E(\cdot)$ identifies the operator mean value and $\sigma$ standard deviation. The purpose of this transformation is to reduce all variables to the same order of size.

As reported in Table 1, all variables are highly correlated. In particular, the following pairs of variables show a correlation of more than 90\%: (net commissions, assets under management), (administrative costs, net commissions), (average number of employees, net commissions), and (administrative costs, average number of employees).

\section{Empirical Results}

Two multivariate regressions are performed, as other dependences did not prove to be significant at the $10 \%$ level. The first one, as reported in Table 2, considers the asset under management as a dependent variable and the number of real estate funds managed and the average number of employees for each SGR as independent variables.

The second multivariate regression, according to Table 3 , considers net commissions as a dependent variable and the number of real estate funds managed, personnel expenses, and AUM as independent variables.

Each regression is performed with reference to two scenarios. The first scenario is represented by the entire data sample, without any distinction between different SGRs, while the second considers the splitting of the sample into clusters, depending on the AUM. Dummy variables are added to perform the latter analysis.

Before analysing the first regression, it should be considered the path followed by SGRs in terms of AUM, number of funds, and percentage of administrative costs in terms of AUM. As reported below, Table 4 represents the amount of asset under management for each SGR, Table 5 represents the number of real estate funds for each SGR, and Table 6 represents the percentage of administrative costs in terms of AUM. Each table refers to the period from 2013 to 2018.

Over the six-year period considered, an increase in investments made in Italy through alternative real estate investment funds is observed. Indeed, the AUM analysed in the sample shows a compound annual growth rate (CAGR) of $7.21 \%$. This increase can be expressed in absolute value as +6.6 billion euro in the last year (2018). Considering the 
TABLE 1: Correlation matrix for each year.

\begin{tabular}{|c|c|c|c|c|c|}
\hline & Net fees & AUM & Administrative costs & No. of real estate funds & No. of employees \\
\hline \multicolumn{6}{|l|}{2013} \\
\hline Net fees & 1.0000000 & 0.9366408 & 0.9203043 & 0.7812385 & 0.7872560 \\
\hline AUM & 0.9366408 & 1.0000000 & 0.8572549 & 0.7694823 & 0.8768293 \\
\hline Administrative costs & 0.9203043 & 0.8572549 & 1.0000000 & 0.8867641 & 0.7720600 \\
\hline No. of real estate funds & 0.7812385 & 0.7694823 & 0.8867641 & 1.0000000 & 0.6830251 \\
\hline No. of employees & 0.7872560 & 0.8768293 & 0.7720600 & 0.6830251 & 1.0000000 \\
\hline \multicolumn{6}{|l|}{2014} \\
\hline Net fees & 1.0000000 & 0.9176423 & 0.9083548 & 0.7871646 & 0.8014534 \\
\hline AUM & 0.9366408 & 1.0000000 & 0.8781287 & 0.8051264 & 0.8657633 \\
\hline Administrative costs & 0.9203043 & 0.8781287 & 1.0000000 & 0.9056471 & 0.7427939 \\
\hline No. of real estate funds & 0.7812385 & 0.8051264 & 0.9056471 & 1.0000000 & 0.6758336 \\
\hline No. of employees & 0.7872560 & 0.8657633 & 0.7427939 & 0.6758336 & 1.0000000 \\
\hline \multicolumn{6}{|l|}{2015} \\
\hline Net fees & 1.0000000 & 0.9477420 & 0.9496365 & 0.7399840 & 0.8903021 \\
\hline AUM & 0.9477420 & 1.0000000 & 0.9168684 & 0.7787273 & 0.8643887 \\
\hline Administrative costs & 0.9496365 & 0.9168684 & 1.0000000 & 0.7687266 & 0.9463153 \\
\hline No. of real estate funds & 0.7399840 & 0.7787273 & 0.7687266 & 1.0000000 & 0.6741669 \\
\hline No. of employees & 0.8903021 & 0.8643887 & 0.9463153 & 0.6741669 & 1.0000000 \\
\hline \multicolumn{6}{|l|}{2016} \\
\hline Net fees & 1.0000000 & 0.9465023 & 0.9509846 & 0.6359986 & 0.9216262 \\
\hline AUM & 0.9465023 & 1.0000000 & 0.8819332 & 0.7457024 & 0.8260694 \\
\hline Administrative costs & 0.9509846 & 0.8819332 & 1.0000000 & 0.5626679 & 0.9609642 \\
\hline No. of real estate funds & 0.6359986 & 0.7457024 & 0.5626679 & 1.0000000 & 0.5183680 \\
\hline No. of employees & 0.9216262 & 0.8260694 & 0.9609642 & 0.5183680 & 1.0000000 \\
\hline \multicolumn{6}{|l|}{2017} \\
\hline Net fees & 1.0000000 & 0.8641211 & 0.9738102 & 0.5489571 & 0.9383796 \\
\hline AUM & 0.8641211 & 1.0000000 & 0.8544921 & 0.7638472 & 0.7778732 \\
\hline Administrative costs & 0.9738102 & 0.8544921 & 1.0000000 & 0.5696372 & 0.9550878 \\
\hline No. of real estate funds & 0.5489571 & 0.7638472 & 0.5696372 & 1.0000000 & 0.5026150 \\
\hline No. of employees & 0.9383796 & 0.7778732 & 0.9550878 & 0.5026150 & 1.0000000 \\
\hline \multicolumn{6}{|l|}{2018} \\
\hline Net fees & 1.0000000 & 0.8886413 & 0.9628419 & 0.5543713 & 0.9310833 \\
\hline AUM & 0.8886413 & 1.0000000 & 0.9130547 & 0.7538074 & 0.8420773 \\
\hline Administrative costs & 0.9628419 & 0.9130547 & 1.0000000 & 0.6393171 & 0.9541886 \\
\hline No. of real estate funds & 0.5543713 & 0.7538074 & 0.6393171 & 1.0000000 & 0.5685592 \\
\hline No. of employees & 0.9310833 & 0.8420773 & 0.9541886 & 0.5685592 & 1.0000000 \\
\hline
\end{tabular}

TABle 2: First multivariate regression.

\begin{tabular}{lcc}
\hline Response & $Y$ & Asset under management \\
\hline Regressors & $X_{1}$ & Number of real estate funds managed \\
Regressors & $X_{2}$ & Average number of employees \\
\hline
\end{tabular}

TABLE 3: Second multivariate regression.

\begin{tabular}{lcc}
\hline Response & $Y$ & Net fees \\
\hline Regressors & $X_{1}$ & Number of real estate funds managed \\
Regressors & $X_{2}$ & Administrative costs \\
Regressors & $X_{3}$ & Asset under management \\
\hline
\end{tabular}

entire reference period, this deviation amounts to approximately +24 billion euro $(+51.8 \%)$.

At the same time, there is an increase in the number of funds $(+181$ alternative real estate investment funds between 2013 and 2018; +73\%). Nevertheless, this growth stopped over the past year. This is illustrated by the smaller increase in the number of funds in 2018: the lowest in the last 6 years with an absolute value of +17 and a growth rate of $+4.11 \%$. On the contrary, the AUM increased by $+10.4 \%$ in 2018 .

The dynamic of administrative costs is related to the amount of AUM and to the number of real estate funds. More considerations about this variable are made later.

Launching the first regression, in all six years considered, we found that the intercept is not significant at the $10 \%$ level. By repeating the regression, we obtain the results reproduced in Table 7 , where only significant regressors at $0.1 \%$ and $1 \%$ level are reported.

In the analysed period (2013-2018), the AUM always depends positively on the average number of employees and the number of funds managed. This empirical evidence shows that by increasing the number of employees by one unit compared to their average number during the year, a higher marginal effect is achieved by a unit increase in the number of funds. This can be interpreted as follows: by increasing the number of employees, the asset management company has more resources to employ in setting up and subsequently managing a new real estate fund and, consequently, new assets from which having fees of management. 
TABLE 4: Amount of asset under management for each SGR from 2013 to 2018 .

\begin{tabular}{|c|c|c|c|c|c|c|}
\hline \multirow{2}{*}{ SGR } & \multicolumn{6}{|c|}{ AUM (bn $€)$} \\
\hline & 2018 & 2017 & 2016 & 2015 & 2014 & 2013 \\
\hline 1 & 9.396 & 9.488 & 8.593 & 7.867 & 8.983 & 9.179 \\
\hline 2 & 7.321 & 7.521 & 6.890 & 6.769 & 7.074 & 3.882 \\
\hline 3 & 4.880 & 5.060 & 4.592 & 5.567 & 5.505 & 4.515 \\
\hline 4 & 7.040 & 5.070 & 5.351 & 5.508 & 5.421 & 5.498 \\
\hline 5 & 5.453 & 4.870 & 3.829 & 3.270 & 2.935 & 2.725 \\
\hline 6 & 4.400 & 3.551 & 3.796 & 3.583 & 3.243 & 3.349 \\
\hline 7 & 3.770 & 3.361 & 3.220 & 3.562 & 3.404 & 2.272 \\
\hline 8 & 3.955 & 2.810 & 1.780 & 500 & 307 & 40 \\
\hline 9 & 3.142 & 2.300 & 1.663 & 1.326 & 840 & 520 \\
\hline 10 & 2.503 & 2.198 & 2.065 & 1.523 & 1.014 & 541 \\
\hline 11 & 2.352 & 2.127 & 1.967 & 1.587 & 1.410 & 1.360 \\
\hline 12 & 1.394 & 1.644 & 1.494 & 1.591 & 1.380 & 1.231 \\
\hline 13 & 933 & 1.266 & 1.392 & 1.411 & 1.469 & 1.482 \\
\hline 14 & 1.053 & 1.033 & 1.120 & 1.151 & 843 & 872 \\
\hline 15 & - & - & 1.135 & 1.139 & 850 & 435 \\
\hline 16 & 1.518 & 1.179 & 1.036 & 931 & 820 & 1.036 \\
\hline 17 & 1.280 & 1.173 & 1.120 & 919 & 1.007 & 1.003 \\
\hline 18 & 1.958 & 1.411 & 1.411 & 773 & 709 & 497 \\
\hline 19 & 1.235 & 1.215 & 804 & 738 & 659 & 620 \\
\hline 20 & 1.152 & 938 & 653 & 592 & 540 & 515 \\
\hline 21 & 1.137 & 985 & 943 & 490 & 501 & 509 \\
\hline 22 & 1.018 & 826 & 814 & 910 & 756 & 682 \\
\hline 23 & 27 & 29 & 259 & 299 & 276 & 356 \\
\hline 24 & 48 & 108 & 171 & 268 & 334 & 390 \\
\hline 25 & 92 & 100 & 107 & 229 & 236 & 236 \\
\hline 26 & 473 & 273 & 117 & 147 & 258 & 311 \\
\hline Tot. & 67.530 & 60.536 & 56.322 & 52.650 & 50.774 & 44.056 \\
\hline
\end{tabular}

Values in italics represent cluster 1, values in bold represent cluster 2, and values in bold italics represent cluster 3 .

On the other side, increasing the number of funds by one unit does not necessarily mean a substantial increase in the SGR's AUM, as there is no minimum quantum leap for setting up a fund. Such a fund could be small in terms of size, with a marginal impact on the SGR's overall AUM. However, such an increase in assets would inevitably involve the use of resources and therefore costs.

The absence of the intercept implies that if the regressors are equal to their average, as a consequence, the AUM is not significantly different from its average.

Multivariate regression is later repeated on clustered data. The dummy explanatory variables ind_cl1, ind_cl2 and ind_cl3 indicate membership in the different AUM-based clusters.

More precisely, the dummy variables split the sample into three clusters, as shown below:

(i) Ind_cl1 relates to the first cluster, which contains SGRs whose AUM is greater than 5 billion euros

(ii) Ind_cl2 relates to the second cluster, which contains SGRs whose AUM is bounded between 2 and 5 billion euros

(iii) Ind_cl3 relates to the third cluster, which contains SGRs whose AUM is less than 2 billion euros
TABLE 5: Number of real estate funds for each SGR from 2013 to 2018.

\begin{tabular}{|c|c|c|c|c|c|c|}
\hline \multirow{2}{*}{ SGR } & \multicolumn{6}{|c|}{ Number of real estate funds managed } \\
\hline & 2018 & 2017 & 2016 & 2015 & 2014 & 2013 \\
\hline 1 & 47 & 43 & 41 & 37 & 36 & 32 \\
\hline 2 & 44 & 42 & 35 & 34 & 33 & 29 \\
\hline 3 & 27 & 27 & 27 & 27 & 26 & 21 \\
\hline 4 & 15 & 8 & 7 & 7 & 7 & 7 \\
\hline 5 & 22 & 22 & 20 & 17 & 12 & 11 \\
\hline 6 & 31 & 32 & 33 & 30 & 28 & 25 \\
\hline 7 & 14 & 12 & 12 & 14 & 13 & 12 \\
\hline 8 & 34 & 23 & 14 & 5 & 2 & 2 \\
\hline 9 & 7 & 5 & 5 & 4 & 2 & 1 \\
\hline 10 & 27 & 25 & 18 & 11 & 7 & 4 \\
\hline 11 & 36 & 32 & 30 & 17 & 13 & 12 \\
\hline 12 & 16 & 17 & 17 & 9 & 9 & 8 \\
\hline 13 & 12 & 14 & 14 & 12 & 10 & 9 \\
\hline 14 & 6 & 5 & 5 & 3 & 3 & 3 \\
\hline 15 & - & - & 6 & 6 & 5 & 3 \\
\hline 16 & 19 & 19 & 19 & 19 & 18 & 15 \\
\hline 17 & 12 & 12 & 9 & 8 & 8 & 8 \\
\hline 18 & 6 & 6 & 3 & 3 & 3 & 3 \\
\hline 19 & 22 & 21 & 20 & 18 & 18 & 15 \\
\hline 20 & 5 & 5 & 4 & 4 & 4 & 3 \\
\hline 21 & 4 & 3 & 2 & 2 & 2 & 2 \\
\hline 22 & 12 & 10 & 8 & 9 & 9 & 4 \\
\hline 23 & 2 & 7 & 7 & 10 & 9 & 9 \\
\hline 24 & 1 & 2 & 2 & 2 & 3 & 3 \\
\hline 25 & 5 & 4 & 3 & 4 & 4 & 4 \\
\hline 26 & 4 & 4 & 3 & 2 & 2 & 4 \\
\hline Tot. & 430 & 400 & 364 & 314 & 286 & 249 \\
\hline
\end{tabular}

In this study, to avoid multicollinearity, the dummy variable Ind_cl3 is not explicitly considered in the regressions.

We now want to test whether membership to different clusters is one of the qualitative variables relevant to the regression. The intercept would be the constant term for the base group with lowest AUM, while for members of the first and second AUM-based groups the constant term would be the intercept plus the coefficient of the membership dummy. Again, the results obtained for each regression are reported after removing any insignificant regressors in Table 8.

For the time interval considered, all variables are at least $5 \%$ significant. In addition, all variables, except the intercept, show positive coefficients. As all the variables are standardised, the negative intercept implies that when all the regressors are zero (i.e., for the lowest AUM group), the expected AUM is obviously lower than the average value.

The regression shows that with obvious differences among clusters, while in 2013 and 2018 the number of employees is the only explanatory variable that influences the AUM, for the period 2014-2017 the number of funds managed is the only one having effects on the AUM. Nevertheless, it is noted that the regressor that identifies the number of funds impacts more modestly than the case in which the data are not clustered. 
Table 6: Percentage of administrative costs in terms of AUM.

\begin{tabular}{|c|c|c|c|c|c|c|}
\hline \multirow{2}{*}{ SGR } & \multicolumn{6}{|c|}{ Administrative costs in $\%$ of AUM } \\
\hline & 2018 & 2017 & 2016 & 2015 & 2014 & 2013 \\
\hline 1 & $0.000271 \%$ & $0.000273 \%$ & $0.000288 \%$ & $0.000331 \%$ & $0.000319 \%$ & $0.000292 \%$ \\
\hline 2 & $0.000277 \%$ & $0.000269 \%$ & $0.000267 \%$ & $0.000269 \%$ & $0.000323 \%$ & $0.000464 \%$ \\
\hline 3 & $0.000305 \%$ & $0.000287 \%$ & $0.000309 \%$ & $0.000219 \%$ & $0.000216 \%$ & $0.000252 \%$ \\
\hline 4 & $0.000503 \%$ & $0.000657 \%$ & $0.000573 \%$ & $0.000364 \%$ & $0.000109 \%$ & $0.000129 \%$ \\
\hline 5 & $0.000311 \%$ & $0.000327 \%$ & $0.000374 \%$ & $0.000355 \%$ & $0.000202 \%$ & $0.000157 \%$ \\
\hline 6 & $0.000268 \%$ & $0.000315 \%$ & $0.000294 \%$ & $0.000343 \%$ & $0.000372 \%$ & $0.000358 \%$ \\
\hline 7 & $0.000182 \%$ & $0.000195 \%$ & $0.000203 \%$ & $0.000196 \%$ & $0.000203 \%$ & $0.000340 \%$ \\
\hline 8 & $0.000184 \%$ & $0.000186 \%$ & $0.000220 \%$ & $0.000336 \%$ & $0.000437 \%$ & $0.004489 \%$ \\
\hline 9 & $0.000194 \%$ & $0.000253 \%$ & $0.000242 \%$ & $0.000184 \%$ & $0.000290 \%$ & $0.000260 \%$ \\
\hline 10 & $0.000255 \%$ & $0.000267 \%$ & $0.000253 \%$ & $0.000291 \%$ & $0.000378 \%$ & $0.000782 \%$ \\
\hline 11 & $0.000347 \%$ & $0.000358 \%$ & $0.000342 \%$ & $0.000337 \%$ & $0.000380 \%$ & $0.000414 \%$ \\
\hline 12 & $0.000421 \%$ & $0.000413 \%$ & $0.000401 \%$ & $0.000283 \%$ & $0.000336 \%$ & $0.000315 \%$ \\
\hline 13 & $0.000500 \%$ & $0.000590 \%$ & $0.000393 \%$ & $0.000378 \%$ & $0.000345 \%$ & $0.000279 \%$ \\
\hline 14 & $0.000311 \%$ & $0.000287 \%$ & $0.000270 \%$ & $0.000258 \%$ & $0.000256 \%$ & $0.000173 \%$ \\
\hline 15 & - & - & $0.000192 \%$ & $0.000252 \%$ & $0.000260 \%$ & $0.000390 \%$ \\
\hline 16 & $0.000513 \%$ & $0.000596 \%$ & $0.000612 \%$ & $0.000595 \%$ & $0.000580 \%$ & $0.000418 \%$ \\
\hline 17 & $0.000306 \%$ & $0.000322 \%$ & $0.000296 \%$ & $0.000366 \%$ & $0.000305 \%$ & $0.000346 \%$ \\
\hline 18 & $0.000443 \%$ & $0.000612 \%$ & $0.000563 \%$ & $0.000890 \%$ & $0.000873 \%$ & $0.001051 \%$ \\
\hline 19 & $0.000555 \%$ & $0.000564 \%$ & $0.000795 \%$ & $0.000805 \%$ & $0.000834 \%$ & $0.000683 \%$ \\
\hline 20 & $0.000191 \%$ & $0.000256 \%$ & $0.000352 \%$ & $0.000384 \%$ & $0.000365 \%$ & $0.000388 \%$ \\
\hline 21 & $0.000203 \%$ & $0.000213 \%$ & $0.000214 \%$ & $0.000417 \%$ & $0.000350 \%$ & $0.000323 \%$ \\
\hline 22 & $0.000401 \%$ & $0.000434 \%$ & $0.000602 \%$ & $0.000505 \%$ & $0.000276 \%$ & $0.000304 \%$ \\
\hline 23 & $0.003491 \%$ & $0.004599 \%$ & $0.000511 \%$ & $0.000515 \%$ & $0.000484 \%$ & $0.000397 \%$ \\
\hline 24 & $0.006215 \%$ & $0.002744 \%$ & $0.001554 \%$ & $0.001071 \%$ & $0.000966 \%$ & $0.001381 \%$ \\
\hline 25 & $0.001138 \%$ & $0.001181 \%$ & $0.001081 \%$ & $0.000463 \%$ & $0.000638 \%$ & $0.000726 \%$ \\
\hline 26 & $0.000270 \%$ & $0.000286 \%$ & $0.000688 \%$ & $0.000669 \%$ & $0.000427 \%$ & $0.000340 \%$ \\
\hline
\end{tabular}

TABLE 7: Coefficients resulting from the first regression.

\begin{tabular}{|c|c|c|c|c|c|c|}
\hline \multicolumn{7}{|c|}{$Y=$ asset under management } \\
\hline Year & Regressor & Estimate & Std. error & $t$ value & $\operatorname{Pr}(>|t|)$ & Adjusted $R^{2}$ \\
\hline 2013 & No. of employees & 0.87683 & 0.09429 & 9.299 & $9.42 e-10^{* * *}$ & 0.7599 \\
\hline \multirow[t]{2}{*}{2014} & No. of employees & 0.5921 & 0.1090 & 5.432 & $1.22 e-05^{* * *}$ & \multirow[t]{2}{*}{0.8257} \\
\hline & No. of r.e. funds & 0.4050 & 0.1090 & 3.716 & & \\
\hline \multirow{2}{*}{2015} & No. of employees & 0.6222 & 0.1157 & 5.380 & $1.4 e-05^{* * *}$ & \multirow{2}{*}{0.803} \\
\hline & No. of r.e. funds & 0.3593 & 0.1157 & 3.106 & $0.00467^{* *}$ & \\
\hline \multirow{2}{*}{2016} & No. of employees & 0.60102 & 0.09916 & 6.061 & $2.47 e-06^{* * *}$ & \multirow{2}{*}{0.8059} \\
\hline & No. of r.e. funds & 0.43415 & 0.09916 & 4.378 & $0.000187^{* * *}$ & \\
\hline \multirow{2}{*}{2017} & No. of employees & 0.5271 & 0.1102 & 4.782 & $8.02 e-05^{* * *}$ & \multirow{2}{*}{0.773} \\
\hline & No. of r.e. funds & 0.4989 & 0.1102 & 4.526 & $0.000152^{* * *}$ & \\
\hline \multirow{2}{*}{2018} & No. of employees & 0.6110 & 0.1097 & 5.570 & $1.34 e-05^{* * *}$ & \multirow{2}{*}{0.8046} \\
\hline & No. of r.e. funds & 0.4064 & 0.1097 & 3.705 & $0.00123^{* *}$ & \\
\hline
\end{tabular}

Signif. codes: ${ }^{* * *} 0.001 ;{ }^{* *} 0.01 ;{ }^{*} 0.05$. All variables exhibit positive coefficients.

TABle 8: Coefficients resulting from the first regression on clustered data.

\begin{tabular}{|c|c|c|c|c|c|c|}
\hline \multicolumn{7}{|c|}{$Y=$ asset under management } \\
\hline Year & Regressor & Estimate & Std. error & $t$ value & $\operatorname{Pr}(>|t|)$ & Adjusted $R^{2}$ \\
\hline \multirow{4}{*}{2013} & Intercept & -0.3292 & 0.1237 & -2.661 & $0.01395^{*}$ & \multirow{4}{*}{0.8288} \\
\hline & No. of employees & 0.3859 & 0.1706 & 2.261 & $0.03349^{*}$ & \\
\hline & ind_cl1 & 1.5280 & 0.4766 & 3.206 & $0.00392^{* *}$ & \\
\hline & ind_cl2 & 0.6940 & 0.2558 & 2.713 & $0.01240^{*}$ & \\
\hline \multirow{4}{*}{2014} & Intercept & -0.42872 & 0.06451 & -6.646 & $8.84 e-07^{* * *}$ & \multirow{4}{*}{0.9375} \\
\hline & No. of r.e. funds & 0.25319 & 0.07031 & 3.601 & $0.00151^{* *}$ & \\
\hline & ind_cl1 & 2.14006 & 0.19282 & 11.099 & $1.03 e-10^{* * *}$ & \\
\hline & ind_cl2 & 0.75379 & 0.15181 & 4.965 & $5.08 e-05^{* * *}$ & \\
\hline
\end{tabular}


TABLE 8: Continued.

\begin{tabular}{|c|c|c|c|c|c|c|}
\hline \multicolumn{7}{|c|}{$Y=$ asset under management } \\
\hline Year & Regressor & Estimate & Std. error & $t$ value & $\operatorname{Pr}(>|t|)$ & Adjusted $R^{2}$ \\
\hline \multirow{4}{*}{2015} & Intercept & -0.48072 & 0.05868 & -8.192 & $2.85 e-08^{* * *}$ & \multirow{4}{*}{0.9479} \\
\hline & No. of r.e. funds & 0.20154 & 0.06283 & 3.208 & $0.00391^{* *}$ & \\
\hline & ind_cl1 & 2.22211 & 0.17092 & 13.001 & $4.40 e-12^{* * *}$ & \\
\hline & ind_cl2 & 1.02272 & 0.14032 & 7.288 & $2.04 e-07^{* * *}$ & \\
\hline \multirow{4}{*}{2016} & Intercept & -0.42832 & 0.07138 & -6.000 & $4.05 e-06^{* * *}$ & \multirow{4}{*}{0.9211} \\
\hline & No. of r.e. funds & 0.31868 & 0.06846 & 4.655 & $0.00011^{* * *}$ & \\
\hline & ind_cl1 & 2.29186 & 0.20763 & 11.038 & $1.15 e-10^{* * *}$ & \\
\hline & ind_cl2 & 0.78153 & 0.14725 & 5.307 & $2.18 e-05^{* * *}$ & \\
\hline \multirow{4}{*}{2017} & Intercept & -0.4801 & 0.1142 & -4.205 & $0.000398^{* * *}$ & \multirow{4}{*}{0.8633} \\
\hline & No. of r.e. funds & 0.3098 & 0.1028 & 3.015 & $0.006599^{* *}$ & \\
\hline & ind_cl1 & 1.9595 & 0.2731 & 7.174 & $4.51 e-07^{* * *}$ & \\
\hline & ind_cl2 & 0.5950 & 0.2003 & 2.970 & $0.007307^{* *}$ & \\
\hline \multirow{4}{*}{2018} & Intercept & -0.5594 & 0.1007 & -5.556 & $1.94 e-05^{* * *}$ & \multirow{4}{*}{0.9052} \\
\hline & No. of employees & 0.3236 & 0.1072 & 3.018 & $0.0068^{* *}$ & \\
\hline & ind_cl1 & 1.7988 & 0.2939 & 6.121 & $5.56 e-06^{* * *}$ & \\
\hline & ind_cl2 & 0.8902 & 0.1523 & 5.846 & $1.02 e-05^{* * *}$ & \\
\hline
\end{tabular}

Signif. codes: ${ }^{* * *} 0.001 ;{ }^{* *} 0.01 ;{ }^{*} 0.05$.

TABle 9: Coefficients resulting from the second regression.

\begin{tabular}{|c|c|c|c|c|c|c|}
\hline \multicolumn{7}{|c|}{$Y=$ net fees } \\
\hline Year & Regressor & Estimate & Std. error & $t$ value & $\operatorname{Pr}(>|t|)$ & Adjusted $R^{2}$ \\
\hline \multirow{3}{*}{2013} & AUM & 0.5571 & 0.1033 & 5.393 & $1.35 e-05^{* * *}$ & \multirow{3}{*}{0.9236} \\
\hline & Administrative costs & 0.4427 & 0.1033 & 4.285 & $0.000238^{* * *}$ & \\
\hline & Number of r.e. funds managed & - & - & - & - & \\
\hline \multirow{3}{*}{2014} & AUM & 0.5242 & 0.1399 & 3.747 & $0.000945^{* * *}$ & \multirow{3}{*}{0.8791} \\
\hline & Administrative costs & 0.4480 & 0.1399 & 3.203 & $0.003693^{* *}$ & \\
\hline & Number of r.e. funds managed & - & - & - & - & \\
\hline \multirow{3}{*}{2015} & AUM & 0.4835 & 0.1237 & 3.910 & $0.000625^{* * *}$ & \multirow{3}{*}{0.9342} \\
\hline & Administrative costs & 0.5063 & 0.1237 & 4.094 & $0.000389^{* * *}$ & \\
\hline & Number of r.e. funds managed & - & - & - & - & \\
\hline \multirow{3}{*}{2016} & AUM & 0.48515 & 0.08832 & 5.493 & $1.05 e-05^{* * *}$ & \multirow{3}{*}{0.9532} \\
\hline & Administrative costs & 0.52311 & 0.08832 & 5.923 & $3.50 e-06^{* * *}$ & \\
\hline & Number of r.e. funds managed & - & - & - & - & \\
\hline \multirow{3}{*}{2017} & AUM & - & - & - & - & \multirow{3}{*}{0.9483} \\
\hline & Administrative costs & 0.97381 & 0.04641 & 20.983 & $6.0142 e-17$ & \\
\hline & Number of r.e. funds managed & - & - & - & - & \\
\hline \multirow{3}{*}{2018} & AUM & - & - & - & - & \multirow{3}{*}{0.9239} \\
\hline & Administrative costs & 0.96284 & 0.05631 & 17.1 & $1.43 e-14^{* * *}$ & \\
\hline & Number of r.e. funds managed & - & - & - & - & \\
\hline
\end{tabular}

Signif. codes: ${ }^{* * *} 0.001 ;{ }^{* *} 0.01 ;{ }^{*} 0.05$.

The second multivariate regression is carried out to verify the dependence of net commissions. Again, the results obtained for each regression are reported in Table 9 after removing any insignificant regressors.

All regression coefficients show positive coefficients. In the range considered, commissions depend positively on assets under management and personnel expenses. Exceptions are the last two years during which net commissions depend only on personnel expenses.

This empirical evidence means that by increasing assets (for all years except 2017-2018) or expenses by one unit compared to their average, a similar marginal effect on net commissions is achieved. The absence of the intercept means that if the regressors are equal to the average, commissions are not significantly different from the average.

The analyses resulting from repeating the multivariate regression on clustered data are exactly the same as those carried out on nonclustered data because clusterization turns out to be not statistically significant. There is no evidence of economies of scale: increasing assets under management or employee expenses increases net commission costs. 


\section{Conclusions}

The analyses carried out so far have not shown any relationship that would suggest economies of scale. The first regression clearly showed that the assets under management, i.e., those capable of generating income, depend on the number of funds managed by each SGR and the number of employees. As the number of funds increases, there is logically an increase in assets. Also by increasing the number of employees, there are more resources able to manage the possible creation of new funds. This last aspect translates in practical terms into higher net commissions to be paid as more resources to be employed, alias costs, and lower profitability.

Since empirical evidence does not provide a modus operandi to be followed to minimize costs and maximize assets under management, it may be thought that the issue is still little known and of great interest to all market participants. This uncertainty suggests policy considerations that deserve to be further investigated.

The absence of economies of scale could be linked to the particular characteristics of each fund and its business model. This consideration deserves to be studied in greater depth. In fact, when a "traditional" fund is established, typically based on big asset located to primary tenants, the management company cannot charge high unit fees. In this case, high volumes managed do not imply high level of cost, but also high revenues to earn. When an innovative fund with high added value to be performed in the management of the assets is established (this implies the presence of unique and not easily replicable assets), the management company may charge higher fees, due to the specificity of the assets, with the consequent risk that management costs increase more than proportionally.

In addition, anyway minimum management costs are imposed by national law and supervisory authorities to protect and safeguard the rights of all stakeholders and of the market. These kinds of costs, for the part directly related to the funds managed, do not allow economy of scale.

In summary, there is no single model for profit maximization and cost minimization, but all depends on the business model that each real estate asset management company decides to adopt and, consequently, on the type of assets that are managed.

\section{Data Availability}

The data used were obtained through the balance sheets that each SGR provided to the Department of Business Economics of the University of Parma.

\section{Conflicts of Interest}

The authors declare that they have no conflicts of interest.

\section{References}

[1] G. Abatecola, A. Caputo, M. Mari, and S. Poggesi, "Real estate management: past, present, and future research directions,"
International Journal of Globalisation and Small Business, vol. 5, no. 1, pp. 98-113, 2013.

[2] J. Dombrow and G. K. Turnbull, "Trends in real estate research, 1988-2001: what's hot and what's not," The Journal of Real Estate Finance and Economics, vol. 29, no. 1, pp. 47-70, 2004.

[3] L. L. Johnson and T. Keasler, "An industry profile of corporate real estate," Journal of Real Estate Research, vol. 8, pp. 455-473, 1993.

[4] M. A. O’Mara, Strategy and Place; Managing Corporate Real Estate for Competitive Advantage, Free Press, New York, NY, USA, 1999.

[5] A. Schmitz and D. L. Brett, Real Estate Market Analysis. A Case Study Approach, The Urban Land Institute, Washington, DC, USA, 2001.

[6] B. P. Singer, B. A. G. Bossink, and H. J. M. Vande Putte, "Corporate real estate and competitive strategy," Journal of Corporate Real Estate, vol. 9, no. 1, pp. 25-38, 2007.

[7] F. Tajani, P. Morano, M. P. Saez-Perez et al., "Multivariate dynamic analysis and forecasting models of future property bubbles: empirical applications to the housing markets of Spanish metropolitan cities," Sustainability, vol. 11, no. 13, 2019.

[8] P. Morano, F. Tajani, and M. Locurcio, "Multicriteria analysis and genetic algorithms for mass appraisals in the Italian property market," International Journal of Housing Markets and Analysis, vol. 11, no. 2, 2018.

[9] N. Barlow and E. Lawson, "Real estate's vital role in corporate finance," Journal of Corporate Accounting \& Finance, vol. 1, no. 4, pp. 361-365, 1990.

[10] J. D. Benjamin, P. Chinloy, and W. G. Hardin, "Local presence, scale and vertical integration: brands as signals," The Journal of Real Estate Finance and Economics, vol. 33, no. 4, pp. 389-403, 2006.

[11] M. B. Trundle, "Capturing hidden value for your shareholders," Journal of Corporate Real Estate, vol. 7, no. 1, pp. 55-71, 2005.

[12] C. Giannotti and G. Mattarocci, "Risk diversification in a real estate portfolio: evidence from the Italian market," Journal of European Real Estate Research, vol. 1, no. 3, pp. 214-234, 2008.

[13] F. J. Acoba and S. P. Foster, "Aligning corporate real estate with evolving corporate missions: process-based management models," Journal of Corporate Real Estate, vol. 5, no. 2, pp. 143-164, 2003.

[14] S. Duckworth, "Realizing the strategic dimension of corporate real property through improved planning and control systems," Journal of Real Estate Research, vol. 8, pp. 495-509, 1993.

[15] A. Lindholm, K. M. Gibler, and K. I. Leväinen, "Modeling the value-adding attributes of real estate to the wealth," Journal of Real Estate Research, vol. 28, pp. 445-475, 2006.

[16] A. Banfi, G. Borello, and F. Pampurini, Una Stima del Livello di Efficienza Delle Società di Gestione del Risparmio Operanti in Italia, Banca d'Italia, Rome, Italy, 2011.

[17] B. W. Ambrose, M. J. Highfield, and P. D. Linneman, "Real estate and economies of scale: the case of REITs," Real Estate Economics, vol. 33, no. 2, pp. 323-350, 2005.

[18] H. Y. Kim, "Economies of scale and economies of scope in multiproduct financial institutions: further evidence from credit unions," Journal of Money, Credit and Banking, vol. 18, no. 2, pp. 220-226, 1986.

[19] B. W. Ambrose, F. Fuerst, N. Mansley, and Z. Wang, "Size effects and economies of scale in European real estate companies," Global Finance Journal, vol. 42, 2019. 
[20] W. McIntosh, Y. Liang, and D. L. Thompkins, "An examination of the small-firm effect within the REIT industry," Journal of Real Estate Research, vol. 6, pp. 9-18, 1991.

[21] P. Linneman, "Forces changing the real estate industry forever," Wharton Real Estate Review, vol. 1, pp. 1-12, 1997.

[22] M. Bers and T. M. Springer, "Economies-of-scale for real estate investment trusts," Journal of Real Estate Research, vol. 14, pp. 275-290, 1997.

[23] M. Bers and T. M. Springer, "Sources of scale economies for REITs," Real Estate Finance, vol. 14, pp. 47-56, 1998.

[24] M. Bers and T. M. Springer, "Differences in scale economies among real estate investment trusts: more evidence," Real Estate Finance, vol. 15, pp. 37-44, 1998.

[25] B. W. Ambrose, S. R. Ehrlich, W. T. Hughes, and S. M. Wachter, "REIT economies of scale: fact of fiction," The Journal of Real Estate Finance and Economics, vol. 20, no. 2, pp. 211-224, 2000.

[26] D. R. Capozza and P. J. Seguin, "Managerial style and firm value," Real Estate Economics, vol. 26, no. 1, pp. 131-150, 1998.

[27] D. A. Latzko, "Economies of scale in mutual fund administration," Journal of Financial Research, vol. 22, no. 3, pp. 331-339, 1999.

[28] D. R. Capozza and P. J. Seguin, "Debt, agency and management contracts in REITs: the external advisor puzzle," The Journal of Real Estate Finance and Economics, vol. 20, no. 2, pp. 91-116, 2000.

[29] R. I. Anderson, R. Fok, T. Springer, and J. Webb, “Technical efficiency and economies of scale: a non-parametric analysis of REIT operating efficiency," European Journal of Operational Research, vol. 139, no. 3, pp. 598-612, 2002.

[30] L. J. Mester, "A study of bank efficiency taking into account risk-preferences," Journal of Banking \& Finance, vol. 20, no. 6, pp. 1025-1045, 1996.

[31] M. L. Bianchi and M. G. Miele, I Fondi Comuni Aperti in Italia: Performance Delle Società di Gestione del Risparmio, Banca d'Italia, Rome, Italy, 2011.

[32] E. Geretto and R. Morassut, "La valutazione delle performance economico-operative delle società di gestione del risparmio," Banche e Banchieri, vol. 6, pp. 452-470, 2010.

[33] G. Abate, "Real estate finance e sgr immobiliari: caratteristiche strutturali e dinamiche reddituali," Bancaria, vol. 3, 2011.

[34] C. Giannotti and G. Mattarocci, "La redditività e l'efficienza delle sgr immobiliari," Bancaria, vol. 69, no. 10, pp. 32-36, 2014.

[35] Banca d'Italia, Rapporto Sulla Stabilità Finanziaria, Banca d'Italia, Rome, Italy, 2019. 